\title{
Comment on "Resource interaction in inter-organisational networks: Foundations, comparison, and a research agenda"
}

\author{
Luis Araujo * \\ Department of Marketing, Lancaster University Management School, Lancaster LA1 4YX, United Kingdom
}

\section{A R T I C L E I N F O}

\section{Article history:}

Received 1 November 2010

Received in revised form 1 March 2011

Accepted 1 April 2011

Available online 13 July 2011

\section{Keywords:}

Resources

Interaction

Penrose

Intraorganisational

Networks

\begin{abstract}
A B S T R A C T
This commentary discusses the article by Baraldi, Gressetvold and Harrison (this issue), which reviews the foundations and implications of the resource interaction perspective. The discussion stresses the Penrosean legacy of this perspective but also its potential to expand the Penrosean framework beyond intraorganisational applications, that is, to an understanding of markets and networks.
\end{abstract}

(C) 2011 Elsevier Inc. All rights reserved.
Baraldi, Gressetvold and Harrison provide a very timely and focused review on how different research traditions have variously interpreted and appropriated the legacy of Edith Penrose. The legacy of Penrose has itself been the subject of some controversy; witness, for example, the debate between Rugman and Verbeke $(2002,2004)$ and Lockett and Thompson (2004).

The edited volume by Pitelis (2001) remains the most comprehensive appraisal of the works and legacy of Penrose. Loasby (2001) provides one of the briefest and most compelling summaries of Penrose's achievements. The first is an account of the firm as an organisation which aids the utilization and creation of knowledge, with its set of resources and administrative structure providing options and reserves for an uncertain future. The second is the seminal distinction between resource and the productive services they render. Defining resources independently of their use means that the same resource used for different purposes, in different ways or indeed in different combinations with other resources, will yield different services (Turvani 2001: 204). Penrose (1959: 75) concluded: "It is the heterogeneity, and not the homogeneity, of the productive services available or potentially available from its resources that gives each firm its unique character".

As Richardson (2001: 41) remarked, the services provided by members of a cooperating group depends on how the group is organised. Independently of the contractual arrangement that holds the group together, there is a requirement for stability so that members of the group can learn how to work together. In Penrosean firms, what

\footnotetext{
* Tel.: + 441524593915.

E-mail address: l.araujo@lancaster.ac.uk.
}

primarily constrains growth is the firm's ability to absorb and integrate managerial services since “... Individuals with experience within a given group cannot be hired from outside the group and it takes time for them to achieve the requisite experience" (Penrose 1959: 47).

Returning to Baraldi, Gressetvold and Harrison's argument, the resource interaction perspective adopts a genuine Penrosean view on resources but it does not stick to firms as cooperating groups, in Richardson's sense. The thrust of the resource interaction perspective is to examine the creation of productive services from combinations of resources that encompass both intra and inter-organisational interfaces. Thus instead of taking firms as the point of departure and seeing them as collection of resources, we can examine how particular collections of resources are organised and coordinated.

This is a marked departure from the modern, resource-based view (RBV) of the firm which insists on looking at the long-term competitive advantage of firms as residing in the bundles of resources that competitors find hard to emulate. This development is an unwelcomed return to a concern with rents in equilibrium which is as far as away as we can get from the Penrosean firm and growth in disequilibrium (Foss, 2001).

The resource interaction perspective can thus look at the collections of resources, the multiple and differentiated services that organisations can obtain from a broad set of combinations without worrying unduly whether these collections are confined to firms. This does not mean to say that we abandon the Penrosean concern with the continuity of association and the importance of managerial and entrepreneurial services in spotting, developing and realising what Penrose (1959: 31) called productive opportunities. On the contrary, the range of productive opportunities is greatly expanded if we do not restrict ourselves to the resources firms own and control but also embrace 
resources that firms can access through relationship with specific counterparts. And continuity of association is no longer restricted to employment contracts and can also reside in organised episodes of interaction in particular business relationships.

The expansion of a Penrosean resource-based view to business relationships and networks requires us to look at both the combination and integration of resources in particular constellations and the administrative structures that allow these constellations to evolve to discover new productive opportunities. The pioneering contribution of G.B. Richardson (1972) ${ }^{* *}$ was precisely to show the possibility of expanding a Penrosean framework to take into account how the division of labour could encompass firms, markets and what he tentatively called "...the dense network of cooperation and affiliation by which firms are interrelated" (Richardson, 1972: 883). As Baraldi, Gressetvold and Harrison remark, this prospect raises important challenges not least appropriate methodologies for capturing processes of distributed, multi-actor resource interaction. It is high time we push ahead with this enterprise.

\section{References}

Foss NJ. Edith Penrose: economics and strategic management. In: Pitelis C, editor. The growth of the firm. The legacy of Edith Penrose. Oxford: Oxford University Press; 2001. p. 147-64.

Loasby BJ. The significance of Penrose's theory for the development of economics. In: Pitelis C, editor. The growth of the firm. The legacy of Edith Penrose. Oxford: Oxford University Press; 2001. p. 45-60.

Lockett A, Thompson S. Edith Penrose's contributions to the resource-based view: an alternative perspective. Journal of Management Studies 2004;41(1):193-203.

Penrose E. The theory of the growth of the firm. Oxford: Basil Blackwell; 1959.

Pitelis C, editor. The growth of the firm. The legacy of Edith Penrose. Oxford: Oxford University Press; 2001.

Richardson GB. The Organisation of Industry. Econ J 1972;82:883-96.

Richardson GB. Mrs. Penrose and neoclassical theory. In: Pitelis C, editor. The growth of the firm. The legacy of Edith Penrose. Oxford: Oxford University Press; 2001. p. 37-44.

Rugman AM, Verbeke A. Edith Penrose's contribution to the resource-based view of strategic management. Strateg Manage J 2002;23(8):769-80.

Rugman AM, Verbeke A. A final word on Edith Penrose. J Manage Stud 2004;41(1): 205-17.

Turvani M. Mismatching by design: explaining the dynamics of innovative capabilities of the firm with a Penrosean mark. In: Pitelis C, editor. The growth of the firm. The legacy of Edith Penrose. Oxford: Oxford University Press; 2001. p. 45-60. 